\title{
The Effect of Aluminium Additions on Characteristic Properties of New High Magnetic Permeability Alloy "Nimalloy" in the System of Nickel and Manganese*
}

\author{
By Hakaru Masumoto**, Yûetsu Murakami** \\ and Masakatsu Hinai**
}

\begin{abstract}
Kobayashi and two of the present authors discovered in a previous work that nickel-manganese alloys exhibit high permeability in the concentration of less than about 24\% manganese, and named them Nimalloy. Much subsequent work has been carried out on the effects of additions of various elements on the properties of nickel-manganese alloys and obtained the highest initial permeability of 76000 and the highest maximum permeability of 441000 . In the present paper, the effect of aluminium additions on the characteristic properties of nickel-manganese alloys have been studied. The results show that the optimum cooling rate for attainment of the highest perrcatility in each alloy increases in general with increasing aluminium content. Thus the alloy containing $78.95 \% \mathrm{Ni}, 19.85 \% \mathrm{Mn}$ and $1.20 \%$ Al showed the highest initial permeability of 10780 when cooled at a rate of $400^{\circ} \mathrm{C} / \mathrm{hr}$ from $900^{\circ} \mathrm{C}$ and the alloy containing $78.81 \% \mathrm{Ni}, \quad 19.56 \% \mathrm{Mn}$ and $1.63 \% \mathrm{Al}$ exhibited the highest maximum permeability of 73200 when cooled at a rate of $800^{\circ} \mathrm{C} / \mathrm{hr}$ from the same temperature; the latter shows a magnetic hysteresis loss of $9.49 \mathrm{erg} / \mathrm{cm}^{3} / \mathrm{cycle}$ and a coercive force of 0.0121 Oe for the maximum magnetic induction of $2000 \mathrm{G}$, and a specific electrical resistivity of $61.0 \mu \Omega$-cm at $20^{\circ} \mathrm{C}$.
\end{abstract}

(Received October 18, 1968)

\section{Introduction}

Kobayashi and two of the present authors(1) discovered in an earlier work that high permeability can be obtained in $\mathrm{Ni}-\mathrm{Mn}$ alloys by properly adjusting the degree of order of the ferromagnetic superlattice $\mathrm{Ni}_{3}$ $\mathrm{Mn}$, and termed these high permeability alloys "Nimalloy". Much subsequent work has since been conducted by Masumoto, Murakami and others on the effects of additions of various elements to $\mathrm{Ni}-\mathrm{Mn}$ alloys on

* This paper was presented at the Autumn Meeting of the Japan Institute of Metals, October 2, 1964, Toyama, Japan. The 23rd report from The Foundation: The Research Institute of Electric and Magnetic Alloys, Sendai, Japan.

** The Foundation: The Research Institute of Electric and Magnetic Alloys, Sendai, Japan.

(1) H. Masumoto, T. Kobayashi and Y. Murakami : Presented at the Spring Meeting of the Japan Institute of Metals, Apr. 5, 1963, Tokyo, Japan; J. Japan Inst. Metals, 29 (1965), 228; Trans. JIM, 8 (1967), 49.

(2) H. Masumoto, T. Kobayashi and Y. Murakami : Presented at the Spring Meeting of the Japan Institute of Metals, Apr. 5, 1963, Tokyo, Japan; J. Japan Inst. Metals, 29 (1965), 1101; Trans. JIM, 8 (1967), 54.

(3) H. Masumoto, T. Kobayashi and Y. Murakami : Presented at the Autumn Meeting of the Japan Institute of Metals, Oct. 19, 1963, Nagoya, Japan; J. Japan Inst. Metals, 30 (1966), 837.

(4) H. Masumoto, T. Kobayashi and Y. Murakami : Presented at the Autumn Meeting of the Japan Institute of Metals, Oct. 19, 1963, Nagoya, Japan; J. Japan Inst. Metals, 31 (1967), 1117.

(5) H. Masumoto, T. Kobayashi and Y. Murakami : Presented at the Spring Meeting of the Japan Institute of Metals, Apr. 5, 1964, Tokyo, Japan.

(6) H. Masumoto, Y. Murakami and M. Hinai : Presented at the Autumn Meeting of the Japan Institute of Metals, Oct. 2, 1964, Toyama, Japan. their characteristic properties. At the biannual Meetings of the Japan Institute of Metals, the results of experiments have been presented for the cases of additions of $\mathrm{Fe}^{(2)}, \mathrm{V}^{(3)}, \mathrm{Si}^{(4)}, \mathrm{Ti}^{(5)}, \mathrm{Mo}^{(5)}, \mathrm{Cr}^{(6)}, \mathrm{Al}^{(6)}$, $\mathrm{Sb}^{(7)}, \mathrm{Sn}^{(7)}, \mathrm{W}^{(8)}, \mathrm{Co}^{(8)}, \mathrm{Cu}^{(8)}, \mathrm{Ge}^{(9)}$ and $\mathrm{Nb}^{(9)}$ to $\mathrm{Ni}-$ Mn alloys as third elements and additions of $\mathrm{Cr}^{(10)}$ and $\mathrm{Mo}^{(11)}$ to $\mathrm{Ni}-\mathrm{Mn}-\mathrm{Fe}$ alloys as fourth elements. The results of measurements of magnetostriction $\lambda_{s}{ }^{(12)-~}$ (14) and crystal magnetic anisotropy energy $K_{1}{ }^{(15)(16)}$

(7) H. Masumoto, Y. Murakami and M. Hinai : Presented at the Spring Meeting of the Japan Institute of Metals, Apr. 6, 1965, Tokyo, Japan.

(8) H. Masumoto, Y. Murakami and M. Hinai : Presented at the Autumn Meeting of the Japan Institute of Metals, Oct. 18, 1965, Fukuoka, Japan.

(9) H. Masumoto, Y. Murakami and M. Hinai : Presented at the Spring Meeting of the Japan Institute of Metals, Apr. 6, 1966, Tokyo, Japan.

(10) H. Masumoto, Y. Murakami and M. Hinai : Presented at the Aụtumn Meeting of the Japan Institute of Metals, Oct. 17, 1966, Amagasaki, Japan.

(11) H. Masumoto, Y. Murakami and M. Hinai : Presented at the Autumn Meeting of the Japan Institute of Metals, Oct. 1, 1967, Sapporo, Japan.

(12) H. Masumoto, T. Kobayashi and S. Kadowaki : Presented at the Autumn Meeting of the Japan Institute of Metals, Oct. 19, 1963, Nagoya, Japan.

(13) H. Masumoto, Y. Murakami and S. Kadowaki : Presented at the Autumn Meeting of the Japan Institute of Metals, Oct. 2, 1964, Toyama, Japan.

(14) H. Masumoto, X. Murakami and S. Kadowaki : Presented at the Spring Meeting of the Japan Institute of Metals, Apr. 6, 1965, Tokyo, Japan.

(15) H. Masumoto, Y. Murakami and N. Nakamura : Presented at the Spring Meeting of the Japan Institute of Metals, Apr. 6, 1966, Tokyo, Japan.

(16) H. Masumoto, Y. Murakami and N. Nakamura : Presented at the Autumn Meeting of the Japan Institute of Metals, Oct. 17, 1966, Amagasaki, Japan. 
which have close bearing upon permeability have also been reported by Masumoto and others on some of these alloys at the JIM's Meetings. Among them, the cases of additions of $\mathrm{Fe}^{(2)}, \mathrm{V}^{(3)}$ and $\mathrm{Si}^{(4)}$ have already been reported in previous publications.

The highest values of initial permeability and maximum permeability obtained so far are as high as 76000 and 441000 , respectively. In this paper the results obtained by additions of aluminium to Nimalloy are described.

\section{Specimens and Experimental Procedure}

Alloying materials used were electrolytic nickel, electrolytic manganese and aluminium, of which the former two were entirely the same as those used in a previous work ${ }^{(1)}$ and the aluminium was $99.82 \%$ in purity. The methods of specimen preparation, heat treatments and measurements will be omitted here because of their similarity. to those reported already ${ }^{(1)}$. The specimens employed were 89 alloys with different compositions of $75.87 \sim 98.36 \%$ nickel, $0 \sim 22.75 \%$ manganese and $0.56 \sim 5.42 \%$ aluminium.

\section{Results and Discussion}

The experimental results are summarized in Table 1 and Figs. 1 8. The specimens with the compositions denoted by the closed circles were at first heated in vacuum at $900^{\circ} \mathrm{C}$ for $\mathrm{l} \mathrm{hr}$ and then cooled to room temperature at ten different cooling rates of $9^{\circ} \mathrm{C} / \mathrm{sec}$, $2800^{\circ} \mathrm{C} / \mathrm{hr}, 1400^{\circ} \mathrm{C} / \mathrm{hr}, 800^{\circ} \mathrm{C} / \mathrm{hr}, \quad 400^{\circ} \mathrm{C} / \mathrm{hr}, 240^{\circ} \mathrm{C} / \mathrm{hr}$, $100^{\circ} \mathrm{C} / \mathrm{hr}, 50^{\circ} \mathrm{C} / \mathrm{hr}, 10^{\circ} \mathrm{C} / \mathrm{hr}$ and $5^{\circ} \mathrm{C} / \mathrm{hr}$. The equivalue curves in Fig. 1 and Fig. 2 are statistically drawn from the highest values of initial permeability $\mu_{0}$ and maximum permeability $\mu_{m}$ against composition, obtained for each specimen. As can be seen from the figures, with increasing aluminium content, $\mu_{0}$ and $\mu_{m}$ generally increase comparatively rapidly and attain maximum values in the manganese-rich region, and then decrease gradually. In general, a series of maximum values runs nearly parallel to a composition line that connects $\mathrm{Ni}_{3} \mathrm{Mn}$ and $\mathrm{Ni}_{3}(\mathrm{Mn}, \mathrm{Al})$. The highest values of 10780 in $\mu_{0}$ and 73200 in $\mu_{m}$ have been obtained in the Ni-Mn-Al system with the composition of $78.95 \% \mathrm{Ni}, 19.85 \% \mathrm{Mn}$ and $1.20 \% \mathrm{Al}$ and of $78.81 \% \mathrm{Ni}, 19.56 \% \mathrm{Mn}$ and $1.63 \% \mathrm{Al}$, respectively. These values are by far larger than the highest values of 6860 in $\mu_{0}$ and 20400 in $\mu_{m}$ of Ni-Mn binary alloys.

Magnetic and electrical properties of the typical alloys in the $\mathrm{Ni}-\mathrm{Mn}-\mathrm{Al}$ system are tabulated in Table 1, where $W_{h}$ is the hysteresis loss, and $\sigma$ is the specific electrical resistivity and $\alpha$ is its temperature coefficient. As shown in the table, the addition of aluminium to Ni-Mn binary alloys improves magnetic properties of the alloys, with larger $4 \pi I$ but with a little change in $\sigma$. Moreover, only the operation of slow cooling from high temperatures suffices to develop excellent magnetic properties of $\mathrm{Ni}-\mathrm{Mn}-\mathrm{Al}$ ternary alloys, and the application of re-heating, as in the case for $\mathrm{Ni}-\mathrm{Mn}$ binary alloys, at temperatures below the order-disorder transformation point is not necessary. This is a great advantage from the point of view of practical applications.

Figs. 3 and 4 show the measured values of $\mu_{0}$ and $\mu_{m}$ against the manganese content for $\mathrm{Ni}-\mathrm{Mn}-\mathrm{Al}$ alloys with the composition near $1.6 \%$ aluminium, after cooling to room temperature from $900^{\circ} \mathrm{C}$ at various cooling rates. Both values of $\mu_{0}$ and $\mu_{m}$ are found generally to have very large peaks.

Figs. 5 and 6 illustrate the alloy composition

Table $\mathrm{I}$ The magnetic and electrical properties of typical $\mathrm{Ni}-\mathrm{Mn}-\mathrm{Al}$ alloys

\begin{tabular}{|c|c|c|c|c|c|c|c|c|c|c|c|c|c|c|}
\hline \multirow[t]{2}{*}{$\begin{array}{l}\text { Alloy } \\
\text { No. }\end{array}$} & \multirow[t]{2}{*}{$\begin{array}{l}\mathrm{Mn} \\
(\%)\end{array}$} & \multirow[t]{2}{*}{$\begin{array}{c}\mathrm{Al} \\
(\%)\end{array}$} & \multirow[t]{2}{*}{$\begin{array}{l}\text { Cooling rate } \\
\text { from } 900^{\circ} \mathrm{C} \\
\left({ }^{\circ} \mathrm{C} / \mathrm{hr}\right)\end{array}$} & \multirow[t]{2}{*}{$\mu_{0}$} & \multirow[t]{2}{*}{$\mu_{m}$} & \multirow[t]{2}{*}{$\begin{array}{c}B(G) \\
\text { for } \\
\mu_{m}\end{array}$} & $\begin{array}{c}W_{h} \\
(\mathrm{erg} / \\
\mathrm{cm}^{3} / \\
\text { cycle })\end{array}$ & $\begin{array}{l}B_{r} \\
(\mathbf{G})\end{array}$ & $\begin{array}{c}H_{c} \\
(\mathrm{Oe})\end{array}$ & $\begin{array}{l}4 \pi I \\
(\mathrm{G})\end{array}$ & $\mid \begin{array}{c}\lambda_{s} \\
\left(\times 10^{-6}\right)\end{array}$ & \multirow[t]{2}{*}{$\begin{array}{c}\sigma \\
(\mu \Omega- \\
\mathrm{cm} \\
\left.20^{\circ} \mathrm{C}\right)\end{array}$} & \multirow[t]{2}{*}{$\left(\begin{array}{c}\alpha \\
\times 10^{-3} \\
0^{\circ} \sim \\
\left.40^{\circ} \mathrm{C}\right)\end{array}\right.$} & \multirow{2}{*}{$\begin{array}{l}\text { Density } \\
\left(\mathrm{g} / \mathrm{cm}^{3}\right)\end{array}$} \\
\hline & & & & & & & \multicolumn{3}{|c|}{$B_{m}=2000 \mathrm{G}$} & \multicolumn{2}{|c|}{$H=9000 \mathrm{e}$} & & & \\
\hline 33 & 21.63 & - & $\begin{array}{c}30 \text { (further heated } \\
380^{c} \mathrm{C}, 50 \mathrm{hr} \text { ) }\end{array}$ & 6860 & 18000 & 891 & 18.30 & 951 & 0.0315 & 2790 & - & 60.7 . & 0.93 & . \\
\hline 35 & 21.80 & - & 5 (further heated & 5090 & 12490 & 626 & 18.50 & 876 & 0.0272 & 2760 & +0.17 & 60.5 & 0.94 & 8.42 \\
\hline 37. & 22.00 & - & $\left.380^{\circ} \mathrm{C}, 50 \mathrm{hr}\right)$ & 5880 & 20400 & 908 & 19.34 & 1052 & 0.0270 & 2804 & 0.00 & 60.7 & 0.93 & - \\
\hline 7 & 20.83 & 0.71 & 50 & 10180 & 26500 & 494 & * 3.30 & * 499 & $* 0.0133$ & 2602 & - & 63.9 & 0.79 & - \\
\hline 14 & 19.85 & 1.20 & 400 & 6370 & 40000 & 534 & * 1.31 & * 833 & $* 0.0074$ & 2879 & +0.17 & 62.8 & 0.85 . & 8.30 \\
\hline " & $\|$ & " & 100 & 10780 & 32700 & 761 & 5.54 & 647 & 0.0137 & 4165 & -0.52 & 56.7 & 1.25 & - \\
\hline 15 & 20.35 & 1.21 & 400 & 3000 & 60000 & 801 & * 3.09 & * 871 & $* 0.0110$ & 2735 & +0.17 & 64.0 & 0.77 & 8.28 \\
\hline " & $\pi$ & $"$ & 100 & 8330 & 30000 & 1067 & 12.95 & 711 & 0.0287 & 4576 & - & 55.1 & 1.62 & - \\
\hline 19 & 19.65 & 1.47 & 1400 & 2940 & 53000 & 801 & * 3.16 & * 871 & $* 0.0108$ & 3274 & - & 62.9 & 0.85 & - \\
\hline 35 & 18.36 & 1.62 & 100 & 3430 & 24300 & 2510 & 19.17 & 1725 & 0.0330 & - & - & - & - & - \\
\hline 36 & 18.87 & 1.60 & 1400 & 4660 & 42000 & 748 & * 3.12 & * 764 & $* 0.0110$ & 3760 & +0.17 & 61.8 & 1.04 & 8.26 \\
\hline 37 & 19.16 & 1.64 & 1400 & 5150 & 65400 & 988 & $* 3.17$ & * 935 & $* 0.0106$ & 3624 & - & 62.7 & 0.87 & 8.24 \\
\hline 39 & 19.56 & 1.63 & 800 & 7350 & 73200 & 1042 & 9.49 & 1370 & 0.0121 & 3590 & +0.17 & 61.0 & 1.12 & 8.24 \\
\hline " & $\pi$ & " & 400 & 10210 & 41200 & 1282 & 9.68 & 1310 & 0.0195 & 4352 & -0.17 & 56.4 & 1.25 & - \\
\hline 40 & 19.85 & 1.64 & 800 & 3700 & 50000 & 1468 & 14.67 & 1725 & 0.0232 & 3863 & +0.35 & 60.2 & 1.00 & 8.23 \\
\hline 44 & 17.97 & 1.84 & 240 & 4410 & 33000 & 1470 & 14.22 & 1574 & 0.0249 & 4705 & 0.00 & 57.6 & 1.10 & 8.24 \\
\hline 48 & 16.35 & 2.11 & 100 & 1500 & 21800 & 2136 & 19.77 & 1645 & 0.0260 & - & - & - & - & - \\
\hline 50 & 17.86 & 2.13 & 1400 & 5880 & 24000 & 854 & 19.78 & 881 & 0.0235 & - & - & - & - & - \\
\hline 51 & 18.86 & 2.13 & 2800 & 2450 & 37300 & 1096 & 12.13 & 1362 & 0.0203 & 3567 & +0.17 & 61.1 & 0.99 & 8.23 \\
\hline 52 & 16.90 & 2.19 & 800 & 3430 & 21700 & 1254 & 19.07 & 1366 & 0.0385 & 3955 & -0.52 & 57.9 & 1.39 & 8.28 \\
\hline
\end{tabular}

* For $B_{m}=1000 \mathrm{G}$. 


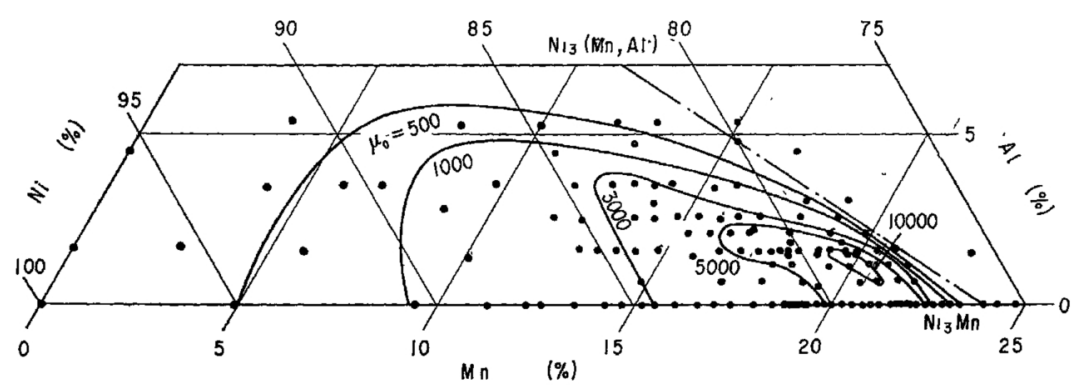

Fig. 1 Highest initial permeability in each of $\mathrm{Ni}-\mathrm{Mn}-\mathrm{Al}$ alloys cooled at various rates after heating at $900^{\circ} \mathrm{C}$ for $1 \mathrm{hr}$

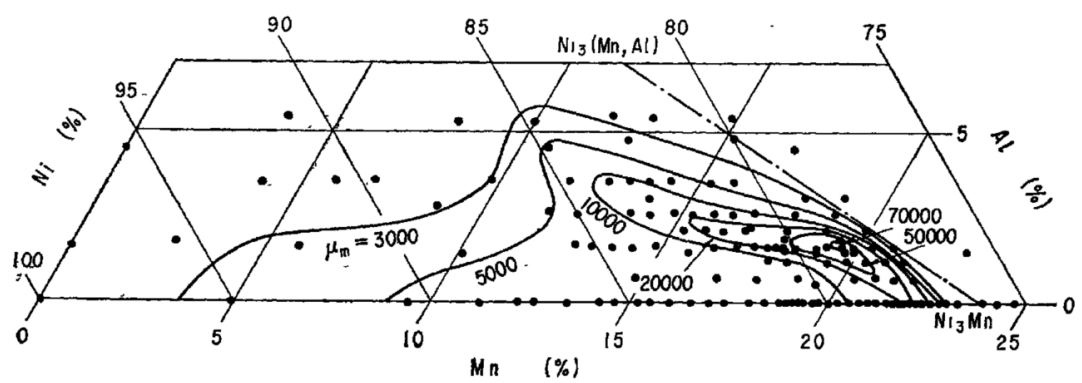

Fig. 2 Highest maximum permeability in each of $\mathrm{Ni}-\mathrm{Mn}-\mathrm{Al}$ alloys cooled at various rates after heating at $900^{\circ} \mathrm{C}$ for $1 \mathrm{hr}$

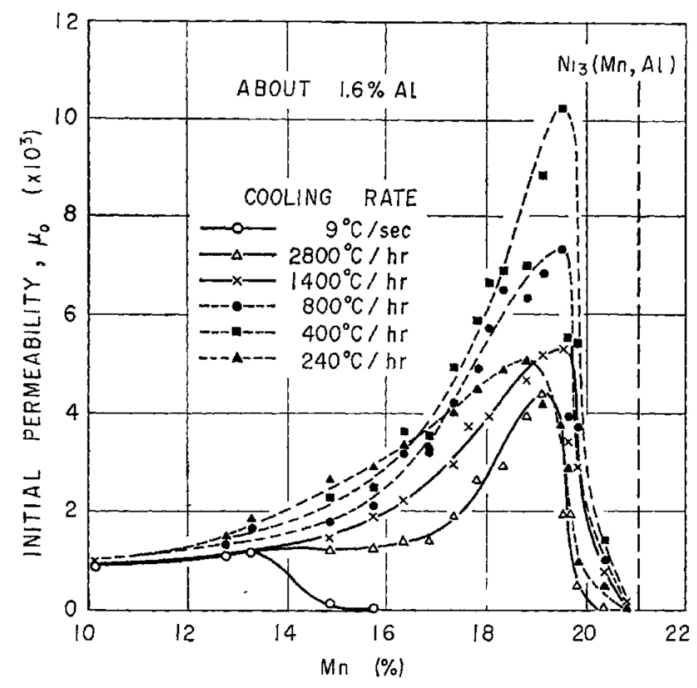

Fig. 3 Initial permeability of $\mathrm{Ni}-\mathrm{Mn}-\mathrm{Al}$ (about 1.6\%) alloys cooled at various rates after heating at $900^{\circ} \mathrm{C}$ for $1 \mathrm{hr}$

dependence of intrinsic magnetic induction $4 \pi I$ and the specific electrical resistivity $\sigma$ which corresponds to the highest $\mu_{m}$ of each specimen obtained by heat treatment, respectively. Fig. 7 shows the same relationship for the ternary alloys with a constant content of near 1.6\% aluminium. As can be seen from these figures, $4 \pi I$ is large and $\sigma$ is small near the composition $\mathrm{Ni}_{3}$ $(\mathrm{Mn}, \mathrm{Al})$, indicating that it is in an ordered state in some extent. Lastly, magnetization and hysteresis curves of No. 39 alloy having the highest maximum permeability are shown in Fig. 8. Although it has been well known that high-permeability alloys have small values of saturation magnetostriction $\lambda_{s}$ it is similarly shown that $\mathrm{Ni}-\mathrm{Mn}-\mathrm{Al}$ alloys of high permeability are extremely small in $\lambda_{s}$ as illustrated in Table 1.

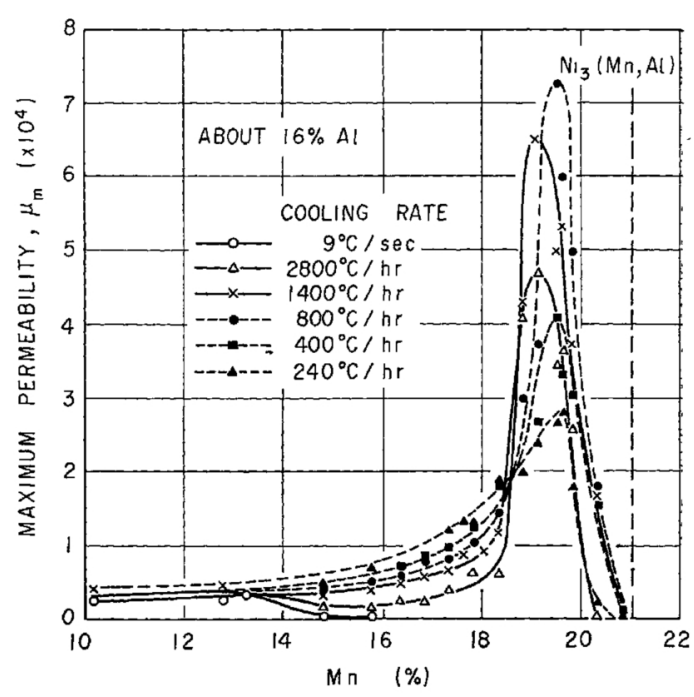

Fig. 4 Maximum permeability of $\mathrm{Ni}-\mathrm{Mn}-\mathrm{Al}$ (about $\mathrm{I} .6 \%$ ) alloys cooled at various rates after heating at $900^{\circ} \mathrm{C}$ for $1 \mathrm{hr}$

In short, as in other high-permeability alloys, high permeability is attained in $\mathrm{Ni}-\mathrm{Mn}-\mathrm{Al}$ alloys by way of reducing $\lambda_{s}$ through a proper adjustment of the degree of order by heat treatment.

\section{Conclusions}

Ring-form specimens were prepared from 89 alloys: of the ferromagnetic $\mathrm{Ni}-\mathrm{Mn}-\mathrm{Al}$ system containing 0 $22.75 \% \mathrm{Mn}$ and $0.56 \sim 5.42 \% \mathrm{Al}$. After heating at $900^{\circ} \mathrm{C}$ for $1 \mathrm{hr}$, the specimens were cooled to room temperature at various cooling rates. The results of measurements of the magnetic properties, specific electrical resistivity and its temperature coefficient are summarized as follows:

(1) In the case of aluminium additions to $\mathrm{Ni}-\mathrm{Mn}$ 


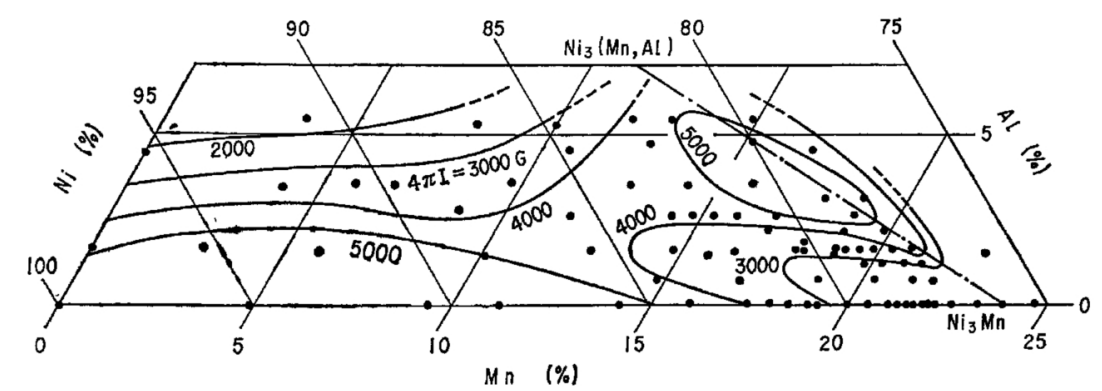

Fig. 5 Intrinsic magnetic induction at an effective field of $900 \mathrm{Oe}$ in $\mathrm{Ni}-\mathrm{Mn}$-Al alloys heat-treated to develop the highest maximum permeability

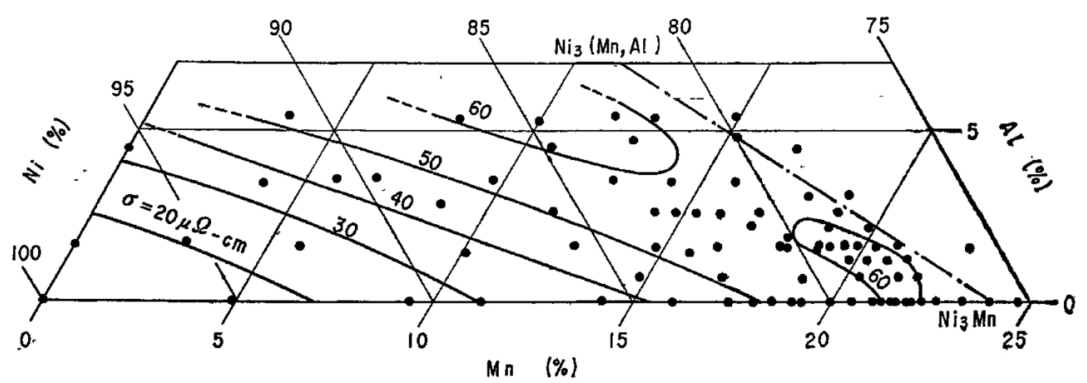

Fig. 6 Specific electrical resistivity at $20^{\circ} \mathrm{C}$ in $\mathrm{Ni}-\mathrm{Mn}-\mathrm{Al}$ alloys heat-treated to develop the highest maximum permeability

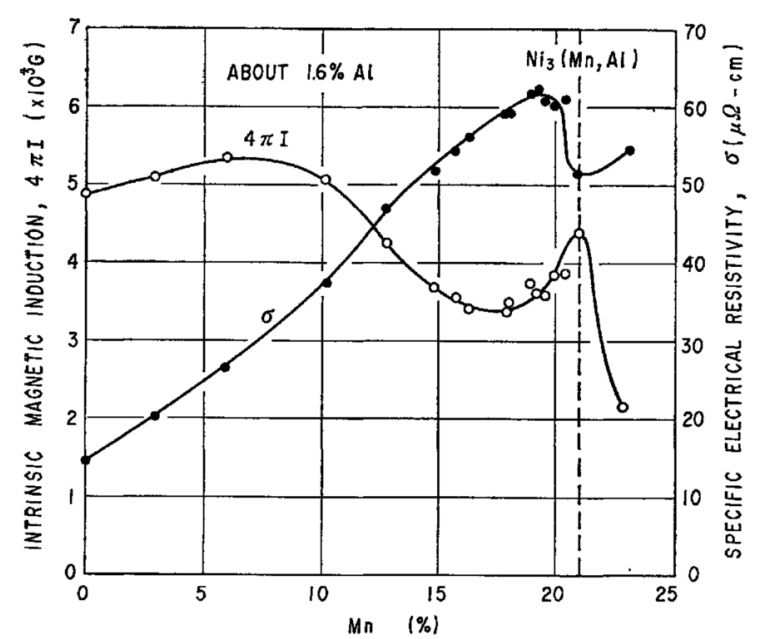

Fig. 7 Intrinsic magnetic induction and specific electrical resistivity at $20^{\circ} \mathrm{C}$ in $\mathrm{Ni}-\mathrm{Mn}-\mathrm{Al}$ (about 1.6\%) alloys heat-treated to develop the highest maximum permeability for each of them

alloys, the cooling rate required for the attainment of the highest permeability increases gradually with increasing ... aluminium content.

(2) With increasing aluminium content, the highest values of $\mu_{0}$ and $\mu_{m}$ obtained for each specimen increase to the maxima and then decrease gradually. The highest values of 10780 in $\mu_{0}$ and 73200 in $\mu_{m}$ have been obtained in the following Ni-Mn-Al alloys: For $\mu_{0}$, composition-78.95\% Ni, $19.85 \% \mathrm{Mn}, 1.20 \% \mathrm{Al}$, cooling rate $-400^{\circ} \mathrm{C} / \mathrm{hr}$; For $\mu_{m}$, composition-78.81 $\% \mathrm{Ni}, 19.56 \% \mathrm{Mn}, 1.63 \% \mathrm{Al}$, cooling rate $-800^{\circ} \mathrm{C} / \mathrm{hr}$.

(3) The Ni-Mn-Al alloy of highest initial perme-

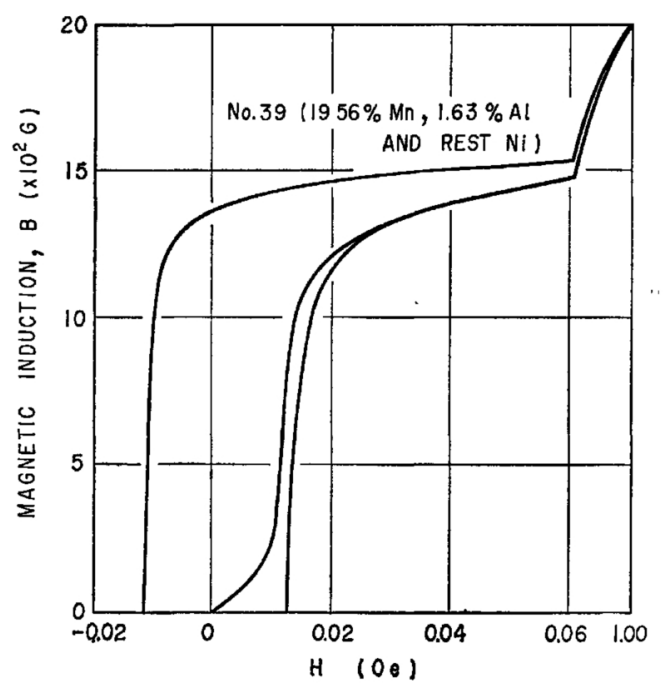

Fig. 8 Magnetization and hysteresis curves of No. 39 alloy

ability with the composition stated above shows the smallest value of $5.54 \mathrm{erg} / \mathrm{cm}^{3} /$ cycle in hysteresis loss, while the smallest value of 0.0121 Oe in coercive force against the maximum magnetic induction of 2000 . G is obtained from the alloy of highest maximum permeability in the $\mathrm{Ni}-\mathrm{Mn}-\mathrm{Al}$ system.

(4) The specific electrical resistivity is generally large. The $\mathrm{Ni}-\mathrm{Mn}-\mathrm{Al}$ alloy of highest maximum permeability shows a value of $61.0 \mu \Omega-\mathrm{cm}\left(20^{\circ} \mathrm{C}\right)$, with a temperature coefficient of $1.12 \times 10^{-3}\left(0^{\circ} \sim 40^{\circ} \mathrm{C}\right)$.

(5) These alloys can more easily be forged and rolled at room and high temperatures than Permalloy. 